\title{
VALIDATING AND EXPANDING THE HAWTHORNE STUDIES: EVIDENCE FROM INDONESIAN PUBLIC EMPLOYEES
}

\author{
I Gede Agus Ariutama \\ Kementerian Keuangan
}

\begin{abstract}
Since Hawthorne study deconstructed Taylor's time and motion studies, scholars of organization studies have shifted their attentions to human relations in the workplaces. The major implication is that employees' relationship with supervisors as well as their peers, and their participation in decision-making process determine productivity. Although the Hawthorne experiments were conducted in the private sector, scholars of public administration believe that the implication from the experiment can be applied to the public sector as well. However, current discussion on the public-private distinction leads to an important research question: can lessons from the Hawthorne study apply to public organizations? The purpose of this study is to validate and expand the original Hawthorne studies and Jung and Lee (forthcoming) conducted in the public organizations by analyzing a large sample of Indonesian public officials. Findings suggest that physical conditions have no or weak impacts on selfassessed and client-evaluated work performance while human relations show positive effects. For the supervisor-assessed performance, participation and physical conditions are the significant predictors. This study gives a unique opportunity since this study investigates the Hawthorne effects in the Asian context for the first time.
\end{abstract}

Keywords: hawthorne studies, human relations, participation, work environment, work requirement, subjective work performance, public-private distinction

\section{INTRODUCTION}

One of the challenges in management has been implementing effective and efficient strategies to improve individual performance and organizational performance accordingly. Taylor (1911) and his associates were among the earliest investigators who developed scientific methods to analyze and synthesize the most efficient workflows to improve production processes and labor productivity.
Among the notions captured in Taylor's scientific management, scientific decision making, standardization, monetary bonus, management training and rest pauses have been widely accepted by modern management (Locke, 1982). However, many criticisms have been addressed to Taylor's concepts especially on oversimplification of the value of workers in terms of social factors, participation and creativity, and motivation (Caldari, 
Validating and Expanding The Hawthorne Studies........ Gede Agus Ariutama 2007). In other words, scientific As mentioned above, the management failed to recognize the importance of social relations in workplace, limited the opportunity for workers to express or participate their ideas (Marshall, 2006), and wrongly overemphasized monetary incentives to motivate workers to determine productivity

(Roethlisberger, 1941).

In respect to Taylor's intention to improve working conditions, the initial study of Hawthorne effects which was expected to measure the relationship between working circumstances and productivity showed no substantial conclusion (Roethlisberger, 1941). Conversely, the subsequent investigations in Hawthorne studies revealed the importance of social factors, specifically human relations and employees' participation to predict workers' output (Mayo, 1933). Thus, Hawthorne studies, which conducted in private plant, provided a foundation for many studies in human relations which brought other scholars to explore its subparts including participation, leadership, satisfaction, and training (Franke and Kaul, 1978). Hawthorne studies were piloted in the private organization. Public organization has more legal restraints, procedural inconsistency, and rigid employees system than private organization (Golembiewski, 1976) resulting in the inferiority of public sector to substantialize the participation of workers and managers (Rainey, 2003). These arguments cast doubt on the applicability of the Hawthorne studies in the public organizations such as training agency. Furthermore, there are only a small number of studies of Hawthorne effects in public sector. For instance, Jung and Lee (forthcoming) investigated Hawthorne studies in the public organizations sampling US federal employees, and their findings were inconsistent with what we know about the Hawthorne effects.

This study aims at achieving two objectives. First, this study is to revalidate Hawthorne effects to check its applicability to public organizations. Second, this study aims to expand discussion on Hawthorne effects from the developed countries context to the 
Validating and Expanding The Hawthorne Studies........ Gede Agus Ariutama developing countries context. To by exploring the application of the meet the objectives, this study model and individual performance in examines the Hawthorne effects by investigating Asian data, specifically public officials of Finance Education and Training Agency (FETA) of the Indonesian Ministry of Finance. Findings show that physical working conditions have positive effects on perceived individual performance, but when human relations are controlled, effects of physical working conditions become weak or insignificant while human relations significantly improve performance. The findings counter to Jung and Lee (forthcoming) clearly confirm the original Hawthorne effects. As one of a little research on Hawthorne effects in Asian public context, this study expects to expand theoretical and practical discussions on human relations and physical working conditions in the Asian public organizations.

First of all, this study begins with a general review of the Hawthorne studies by presenting the significance of the social and physical environment to predict the employees' performance. Second, Revisiting Hawthorne Studies the Hawthorne model is reexamined 
Validating and Expanding The Hawthorne Studies I Gede Agus Ariutama

Hawthorne studies were the

first-known and the most important research of human aspects and working conditions on workers' productivity in the 1920s. These experiments were started with the inquiry about the relationship between illumination intensity levels and efficiency of workers. Surprisingly, the results revealed that despite the illumination level changes, the productivity of the workers increased constantly (Mayo, 1933). In other words, there was no relationship between physical conditions and variations in productivity. Failing to find relationship between physical circumstances and output, the investigators started to take into consideration social relations aspects in the studies (Roethlisberger and Dickson, 1967). In fact, it was found out that worker's efficiency - in illumination experiments, relay room studies, mica splitting analysis, interview sessions and bank wiring studies - was determined by the social interactions with other partners and supervisor and his participation in the group (Roethlisberger, 1941). Therefore,
Hawthorne experiments mostly investigated the influence of social relations with peers and management, participation, physical work environment and requirement on workers' output level with the first two variables were the significant determinants to workers' performance (Jones, 1990; Rainey, 2003).

However, there have been debates about the fundamental interpretations, and significance of the studies (Jones, 1990). Based on the descriptive secondary sources from Mayo (1933) and Roethlisberger and Dickson (1967), and findings from illumination researches, Hart (1943) and Landsberger (1958) claimed that productivity of the workers were the results of social relations among members and between workers and supervisor. Lack of comprehensive statistical analysis, Franke and Kaul (1978) argued that the findings from previous studies on Hawthorne effects were merely opinions and assumptions. They conducted the first statistical analysis to determine workers' productivity level using data and information from the first 
Validating and Expanding The Hawthorne Studies........ Gede Agus Ariutama

relay experiment. The experimental factors, specifically rest time, raw materials quality, and managerial discipline combined with external aspect such as economic condition were able to predict most of the variance of output of workers, meaning that human interactions should not be bothered to explain the quantity and quality of output.

Using the same data as Franke and Kaul (1978), Jones (1990) modified the study by elaborating workers' interdependence in the model, resulting in different outcomes. He found that the effect of rest pauses, economic recession, raw materials quality and group incentive payment was weaker as workers' interdependence variable was introduced. Jones (1992) further mentioned that original data of Hawthorne studies were limited and incomplete to investigate the valid effects due to the lack of data on the control group. In that respect, Jung and Lee (forthcoming) reexamined possible Hawthorne effects in American federal workforce. Furthermore, considering the difference between private and public setting, they claimed that reevaluating the Hawthorne studies in public organization was valuable. However, their investigation suggested inconsistent results with the original Hawthorne effects. Thus, the present study attempts to revalidate the original Hawthorne effects in the private company as well as Jung and Lee (forthcoming) implemented in the public organization. This study analyzes Hawthorne studies in Asian context, specifically Indonesian public officials. Will the finding apply to the public context?

\section{Model of Hawthorne Studies in Public Organization Setting}

Among several investigations in the Hawthorne studies, many scholars focused their attention on the first relay assembly test room due to the main experiment and availability of statistical data collected by Franke and Kaul (Izawa, French, and Hedge, 2011). The first relay mainly examined four variables, specifically physical work environment, physical work requirement, management and supervision and social relation 
Validating and Expanding The Hawthorne Studies........ Gede Agus Ariutama (Franke and Kaul, 1978; Parsons, clients. However, employees' 1978; Olson, Verley, Santos and performance assessed by supervisor Salas, 2004). Thus, several studies also emphasized the four variables to measure workers' performance (e.g. Blombaum, 1983; Jones, 1992; and Jung and Lee, forthcoming). Different from other researches, Jung and Lee's study (forthcoming) tried to reexamine the Hawthorne studies in the public sector based on the first relay assembly. They incorporated physical work environment, physical work requirement, social relations and participative management to measure work group quality.

The present study adopted Lee and Jung's model with several modifications. Overall, this study models work performance as a function of social relations, participation, physical work environment, and physical work requirement along with some other control variables. As described in figure 2.1., instead of measuring work group performance, this study featured subjective individual performance from three perspectives, self-evaluation, supervisor and and clients were in the form of employees' perceptions. Expected relationships between each explanatory variable and work performance will be discussed in the following section.

Satisfaction with relations
among employees and between
superior and subordinates is expected
to have positive and significant relationship with perceived work performance. Furthermore, as employees are more satisfied with their participation, their performance improves. Regarding work circumstances and requirement, employees' perceived performance is likely to be influenced positively by the perception of the employees on physical condition and their working hours. Hence, this study attempts to analyze the effect of social and physical factors upon employees' performance to denote the major experiment of the Hawthorne studies in the public organization setting as presented in figure 2.1. 
Figure 1. A Model Of Hawthorne Studies In Public Organization Setting

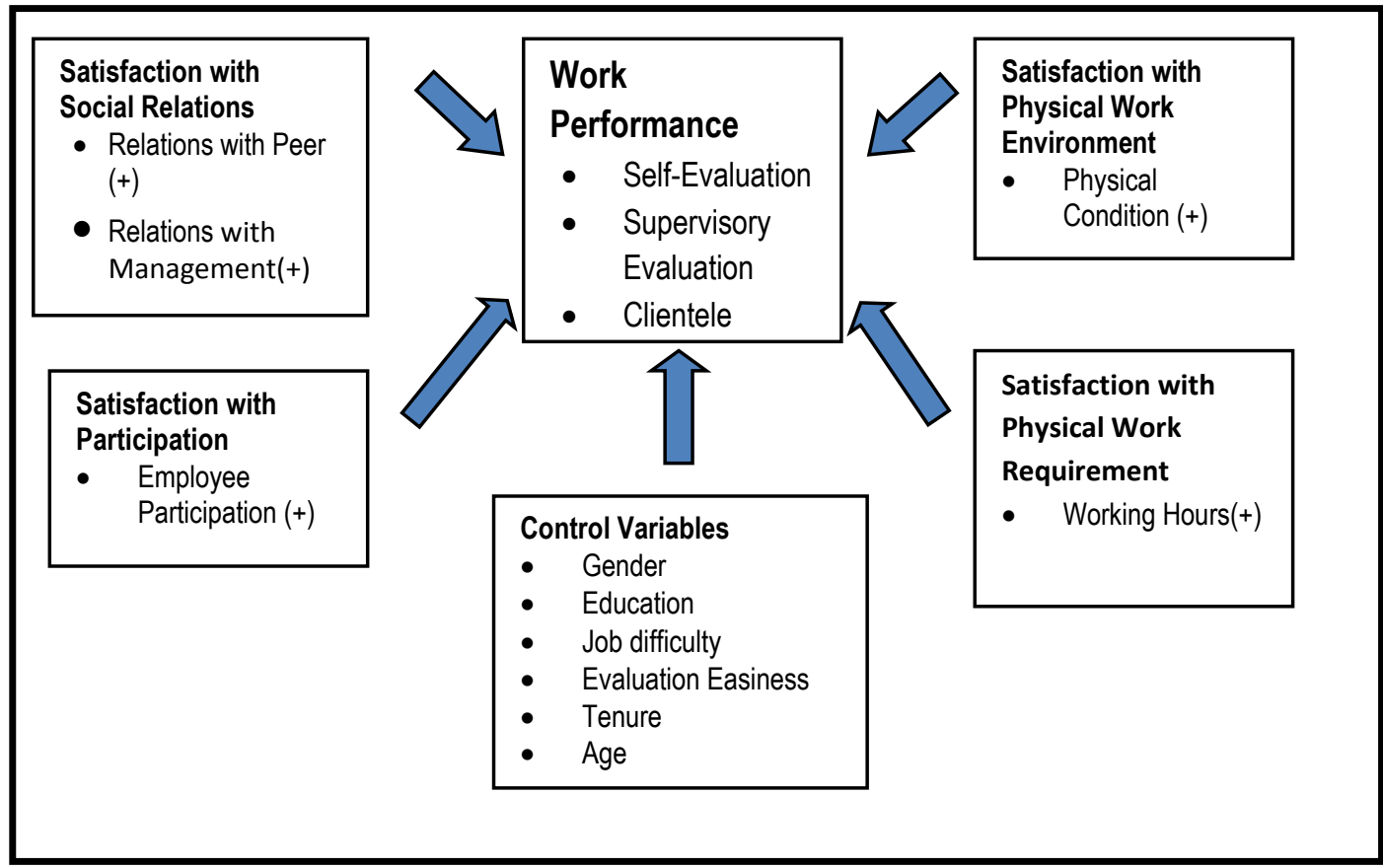

\section{Social Relations and Performance}

As discussed above, the main experiment of Hawthorne studies revealed that the performance of the workers in the form of output quantity and quality was best predicted by workers relations with colleagues and management (Roethlisberger, 1941). Employees having a beneficial relationship with supervisor tend to finish their job well (Homans, 1992), whereas, those experiencing lack of friendly and warm relationship with coworkers and superiors undergo deteriorating productivity (Landsberger, 1958). Landsberger (1958) claimed that workers' performance in the group was more associated with with social relations in terms of friendship (Jehn and Shah, 1997), trust (Dirks, 1999), respect and knowledge sharing are the determinants of employees' perceived performance. As the hierarchical relationships were designed and relied upon trust and fairness among individuals, vertical (management) and horizontal (colleagues) ties of formal and informal cooperation are linked with successful outcome (Ring and Van de Ven, 1994; Ouchi, 1980). In line with the explicit studies above, regarding the connection between management or peer social relation and perceived performance, the 
Validating and Expanding The Hawthorne Studies........ Gede Agus Ariutama author suggests the following two Furthermore, Rainey (2003) claimed hypotheses:

H1: Employees' perception of human that organizations promoting more relation with peers influences the perception of the employees on performance positively.

H2: Employees' perception of human relation with management influences the performance of employees as perceived by the employees themselves positively.

\section{Participation and Performance}

Although relationship between workers' participation in decision making and their performance has been the interest of social scientists, only several empirical studies indicated positive relationship (Likert, 1967; Wagner, 1994). Kim (2002) argued that management permitting sensible involvement and participation of employees in making decision and solving problem will result in greater individual satisfaction and performance. That is, as employees are involved in decision making process, they will have better understanding and acceptance in their responsibilities which result in better execution of their tasks. 
Validating and Expanding The Hawthorne Studies........I Gede Agus Ariutama

H3: Employees' satisfaction with their participation increases perceived performance of employees.

\section{Physical Work Environments and Performance}

In the Hawthorne studies, physical factors did not affect performance significantly. Snow (as cited in Izawa, French and Hedge, 2011) mentioned that better productivity of the workers in the illumination experiments of Hawthorne studies was not related to the illumination level changes, but to the supervisory factor. Wang and Novak (2010), in their study on the relationship between indoor noise and task performance, further claimed that there is no relationship between environment and task performance. They argued that the effect of noise was linked with the subjective perception which was often inconsistent so that the meaning of ideal environment to influence performance became absurd.

However, several studies reassessing Hawthorne studies recommended positive relationship between worker's performance and work environment involving temperature and noise (Baron, 1994). As the workers dissatisfied with the physical conditions such as warmer temperature and louder noise, they felt more tired and their work rate level declined resulting in error increase and performance degradation (Witterseh, Wyon and Clausen, 2004). Newsham et al. (2009) claimed that when the organization seriously maintains the good condition and facilities of office especially lighting, temperature, air quality and acoustic as well as privacy carefully, employees will feel more satisfied since they feel valued by the management. In other words, preserving the good conditions of office and its facilities indicates how valuable are the employees to the organization (Marquardt, Veitch, and Charles, 2002). The justification of this subject is often understood as "a better environment means a happier worker, and happier workers make for a more productive workplace" (Newsham et al., 2009, p. 130).

Given the controversial arguments about the role of physical working condition, this study re- 
Validating and Expanding The Hawthorne Studies........ Gede Agus Ariutama examine the impacts of physical and leisure and may result in working condition on performance by hypothesizing as following:

H4: Employees' satisfaction with physical conditions may influence employees` perceived performance positively.

\section{Physical Work Requirement and Performance}

Other than physical work environment, Franke and Kaul (1978) identified physical work requirement as parts of scientific management which received less attention to predict performance. In their study, working hours was one of the variables included in the physical work requirement. They argued that reduction of working hours per day and working days per week is intended to reduce tiredness and increase productivity. Moreover, undesired working hours and rest time which increased exhaustion resulted in performance reduction (Mortagy and Ramsey, 1973). Regarding work life balance, White, Hill, McGovern, Mills and Smeaton (2003) argued that extended working hours accompanied by work intensity reduce the employees' family time

exhaustion, apprehension or other adverse psychological and physiological effects that can decrease the quality of home and work. This work-life conflict concept could be characterized by a lack of fit between workers, their life and the objectives of organization (Becker and Huselid, 1998). Thus, satisfaction on working hours can be correlated with the individual job satisfaction and performance. Related to the physical work requirement and employees' performance, the author offers one hypothesis:

H5: Employees' satisfaction with working hours increases employees perceived performance.

\section{Data and Sample}

This study aims at validating and expanding Hawthorne studies in the context of Asian public employees. To meet the objective, the author collected data by surveying employees of Finance Education and Training Agency (FETA), Indonesian Ministry of Finance. FETA along with other vertical units under Ministry of 
Validating and Expanding The Hawthorne Studies........ Gede Agus Ariutama

Finance has pioneered bureaucracy reform which one of the focuses is human resource. FETA whose duty is to train and educate all government officials in Indonesia regarding state finance and assets is one of the units responsible for the accomplishment of human resource reform in Ministry of Finance. Therefore, the performance of FETA will affect other units' performance in terms of employee development and competency-based management implementation. Considering its functions and reform obligation, the present study is influential to measure the success of human resource reform implementation in FETA. Cautious generalization of the present study to the Indonesian public official circumstances should be heeded since every organization has its own functions and characteristics. Furthermore, organizations implementing bureaucracy reform might put different emphases and features from those of FETA.

The unit analysis of this study is employees of FETA specifically echelon 4 managers and regular staffs in order to know the effect of human relation and participative management in the smallest unit. Echelon 4 manager is a structural position in the first level management whose responsibilities are leading the smallest unit in the organization and handling the organization's daily operations with clients and employees (Government Regulation of structural promotion for public official number 13, 2002). The lowest and the highest ranks allowable for this position are III/b and III/d consecutively.

The total population of this study is 945 (118 first-line managers and 817 regular staffs). The author sent questionnaire to 500 randomly chosen employees (72 first-line managers and 428 regular staffs). Of the 500 FETA employees who received the questionnaires, 255 completed and returned them (35 first-line managers and 220 regular staffs) for a response rate of $51 \%$.

\section{Variables}

\section{Dependent Variables}

This study exercises three dependent variables in the form of subjective performance measures, specifically self-evaluation and 
Validating and Expanding The Hawthorne Studies........ Gede Agus Ariutama

evaluation by supervisor as well as clients as perceived by the employees. There is some criticism regarding perceptive performance measure. For instance, Meier and O' Toole (2013) concern the validity of subjective performance measures by arguing that the respondents tended to perceive their organization (or their performance) more positive than the objective measures. This could generate deceptive findings for the independent variables to predict the performance. Furthermore, when comparing the subjective and objective performance measures, they found that both measures were not closely associated.

However, perceptive performance measures are merited in this study for several reasons. First, as Brewer and Selden (2000) argued, in a socially constructed world, perceptive measure of performance well represented individuals' performance and their behaviors. When objective performance measures lack, individuals rely on perception to evaluate their performance. Moreover, perceptive performance measures are relevant to the FETA employees. In Ministry of
Finance including FETA, employees' performance is evaluated by every employee's self-evaluation on their own achievement based on the criteria and targets set by himself and his direct supervisor. Additionally, 360-degree evaluation by co-workers, subordinates and direct supervisor as well as clients' satisfaction are employed to evaluate each employee. Therefore, perceptual performance measures capture individual performance quite well.

To measure individual performance, the survey asked the following three questions in the form of 5-point Likert item ranging from 1 (very poor) to 5 (very good): "How would you rate the overall quality of work done by yourself?" (selfevaluation), "How would your supervisor evaluate your work performance?" (supervisor's evaluation) and "How would your clients evaluate your work performance?" (client's evaluation).

\section{Independent Variables}

This study incorporates four groups of explanatory variables: human relations, employee participation, physical work 
Validating and Expanding The Hawthorne Studies I Gede Agus Ariutama environments and physical work participation variable, the average of requirement. There are two independent variables in the human relations: relations with peers and relations with management. In relations with peers, two survey items which were measured using 5point Likert scale ranging from 1 (strongly disagree) to 5 (strongly agree) were included. The author averaged the two survey items about cooperation and knowledge sharing among coworkers. The actual questions and their reliability score are listed in table 3.1. Similar to relations with peers, the survey items in relations with management assessing trust and confidence, cooperation and working relations between employees and managers were measured using a 5-point Likert scale from 1 (strongly disagree) to 5 (strongly agree). The author calculated the average of three items in this variable. For employee three survey items concerning involvement of employees on decision making and overall participatory practice was used. The reliability coefficient of the three survey items ranging from 1 (strongly disagree) to 5 (strongly agree) is 0.717 (see table 3.1 for actual questions).

The physical work
environments include one
independent variable, specifically physical condition which was calculated by a 5-point Likert scale. The survey question for physical condition includes the states of noise level, temperature, lighting, and cleanliness in the office. The physical work requirement covers one explanatory variable: working hours. A 5-point Likert-type scale was employed to measure the satisfaction of employees on their working hours.

Table 1. Reliability of Likert - Scale Type Variables

\begin{tabular}{|l|l|c|}
\hline Variables & Questions & Cronbach's Alpha \\
\hline $\begin{array}{l}\text { Relations } \\
\text { peers }\end{array}$ & $\begin{array}{l}\text { The people I work with cooperate to } \\
\text { get the job done }\end{array}$ & \multirow{2}{*}{0.705} \\
\cline { 2 - 3 } & $\begin{array}{l}\text { Employees in my work unit share job } \\
\text { knowledge with each other }\end{array}$ & \multirow{2}{*}{0.707} \\
\hline $\begin{array}{l}\text { Relations with } \\
\text { management }\end{array}$ & $\begin{array}{l}\text { I have trust and confidence in my } \\
\text { supervisor. }\end{array}$ & \multicolumn{2}{|c|}{$\begin{array}{l}\text { Managers/supervisors/team leaders } \\
\text { work well with employees of }\end{array}$} & \\
\hline
\end{tabular}


Validating and Expanding The Hawthorne Studies

I Gede Agus Ariutama

\begin{tabular}{|c|c|c|}
\hline & different backgrounds. & \\
\hline & $\begin{array}{l}\text { The employees, managers and head } \\
\text { of office have a good working } \\
\text { relationship. }\end{array}$ & \\
\hline \multirow[t]{3}{*}{$\begin{array}{l}\text { Employee's } \\
\text { participation }\end{array}$} & $\begin{array}{l}\text { Decision making in my unit is a } \\
\text { result of employees' discussion. }\end{array}$ & \multirow{3}{*}{0.717} \\
\hline & $\begin{array}{l}\text { Employees are consulted about the } \\
\text { decisions that affect their works. }\end{array}$ & \\
\hline & $\begin{array}{l}\text { Overall, I am satisfied with the } \\
\text { participatory practice in my office. }\end{array}$ & \\
\hline
\end{tabular}

In order to control for factors

which could influence the dependent variables other than explanatory variables and generate more thorough understanding of the model in this study, the demographic information of respondents and characteristics of performance evaluation were exercised. The demographic information of the respondents to be included in the model is gender, education level, job difficulty level, tenure, and age. Moreover, easiness of employee's performance evaluation is included in the model. All data of control variables are obtained from questionnaires.

\section{Methodology}

Since the dependent variables which are subjective performance measures are ordinal responses ranging from 1 (very poor to 5 (very good), ordered logit model is hypotheses. According to Wan, Zhang and Wang (2014), since the dependent variables are hierarchical, the most applicable model to implement is the ordered logit regression. They further described that the ordered logit model is usually defined in the form of cumulative probabilities. The initial model includes physical work environment and requirement as well as control variable. Then, social relations and participation variables are introduced in order to know the consistency of the effect of work environment and requirement on performances when social and psychological factors are incorporated in the model.

The dependent variables in this study confirm the parallel regression assumption, assuming that the covariates have similar impacts as the dependent variables shift from 
Validating and Expanding The Hawthorne Studies........ Gede Agus Ariutama one category to the others (Liang and comprehend for laypersons and Chaloupka, 2002), so that ordered provides a summary of the net logit and odds ratio are employed. impacts of predictors by specifying Odds ratio is uniform for all the multiplicative effects on the odds categories of the variable when for one unit increase in a provided referring to ordinal responses predictor, net of all other variables in (Whitehead, 1993). DeMarris (1993) the model. Thus, raw coefficient, argued that odds ratio better standard error and odds ratios as well interprets logit results than as significance level will be probabilities since it is easier to displayed in the results part. 
Table 2. Correlation and summary of variables in the study

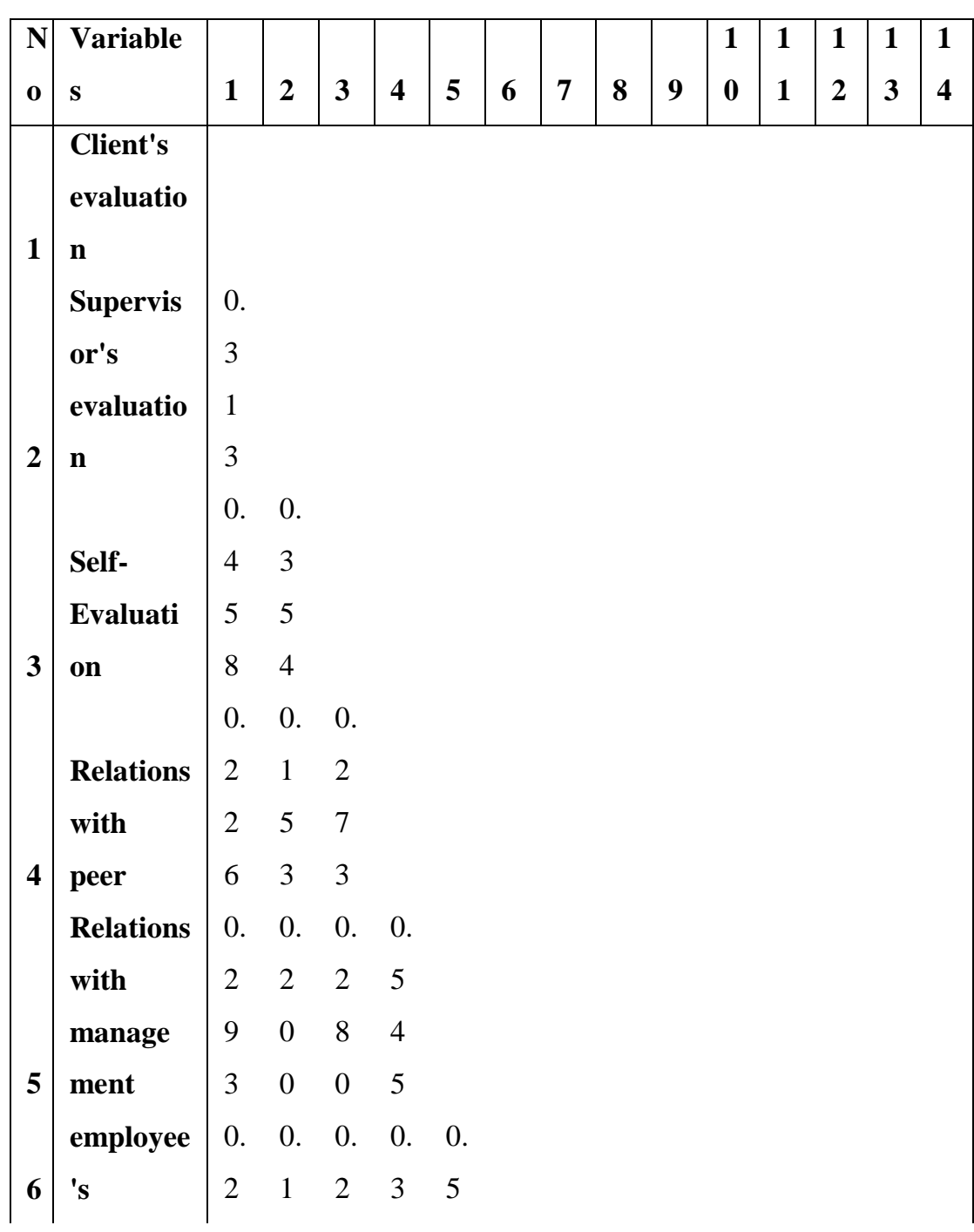

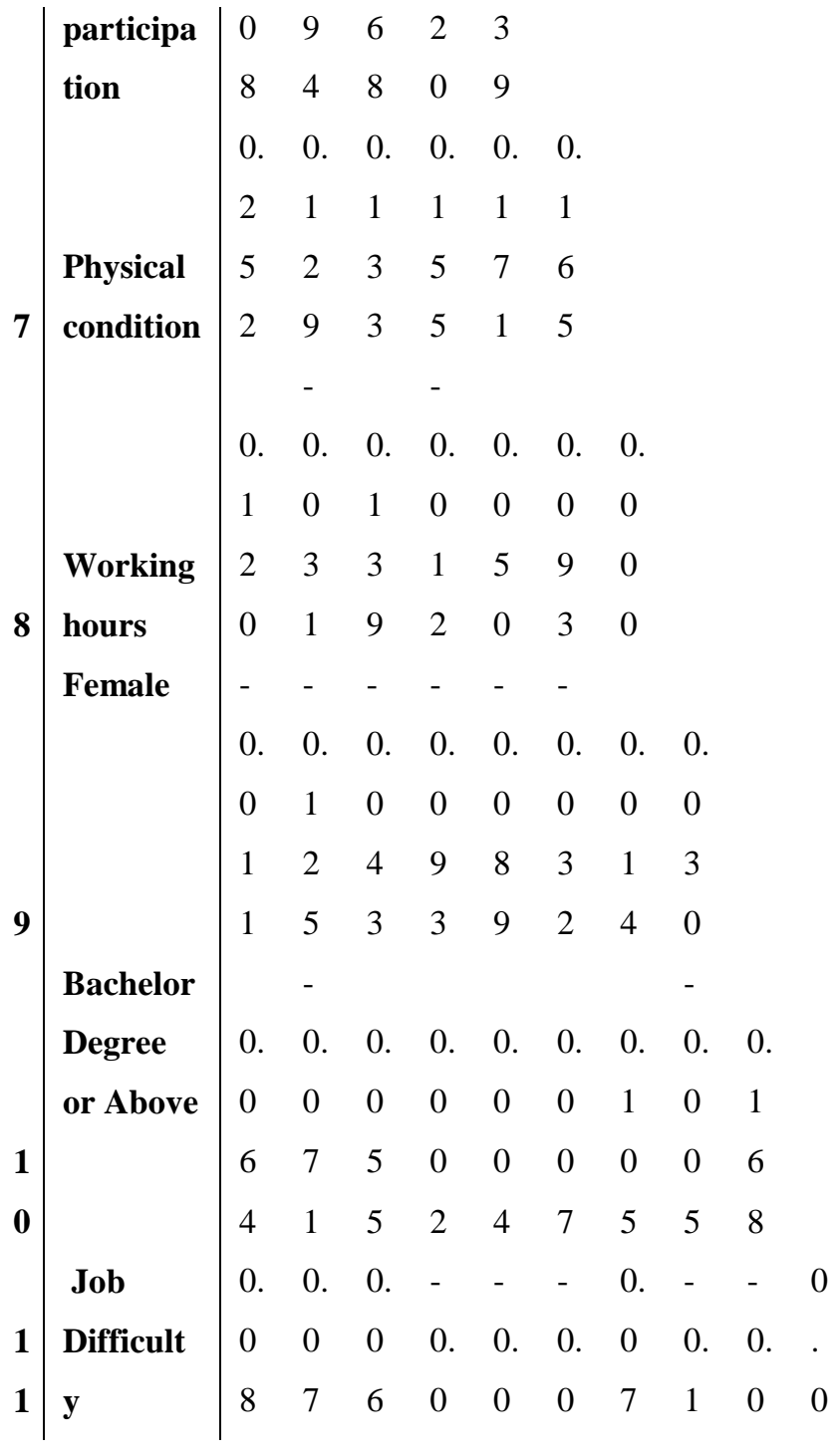




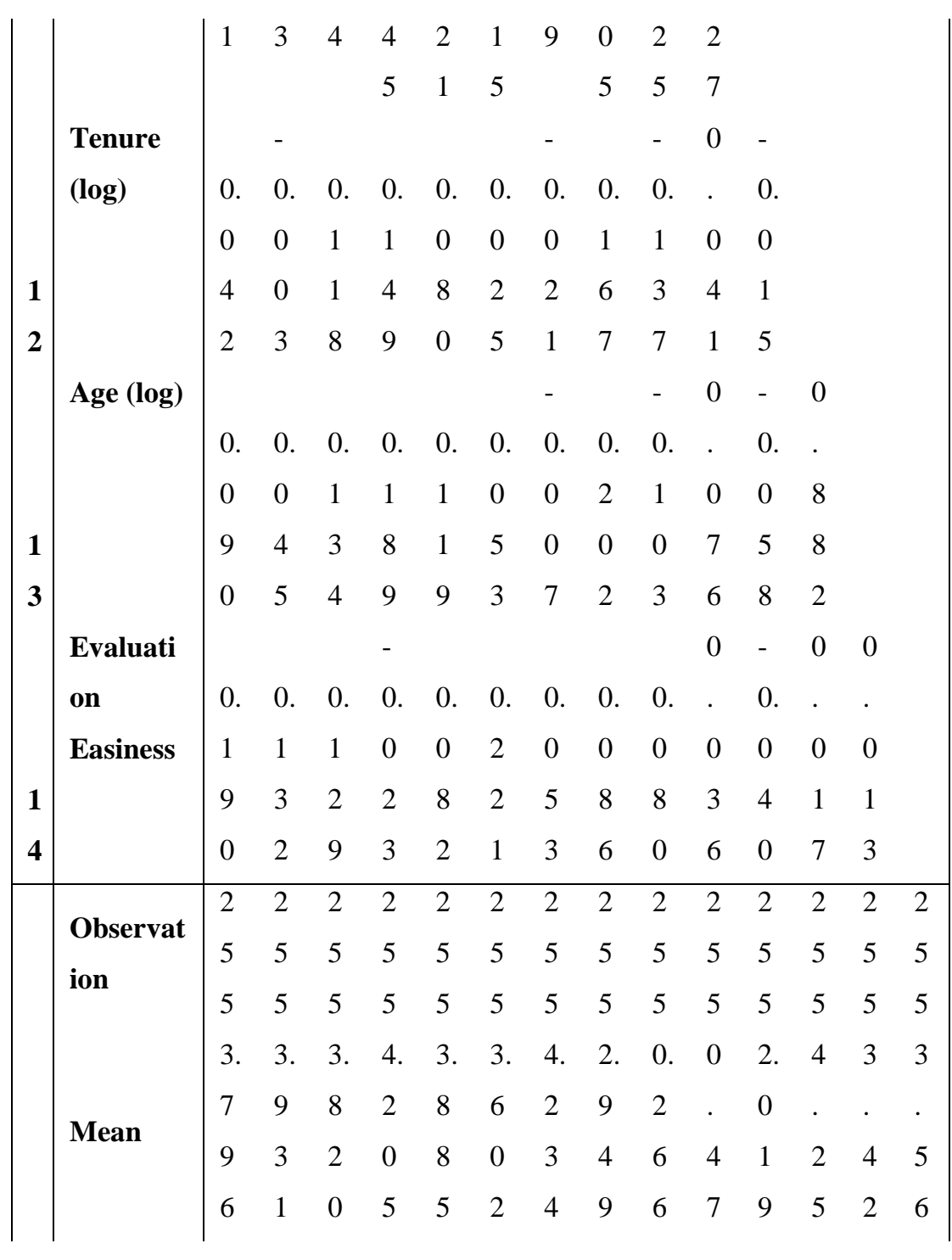

Jurnal Ekonomi Pembangunan Vol.13, No.01 Juni 2015

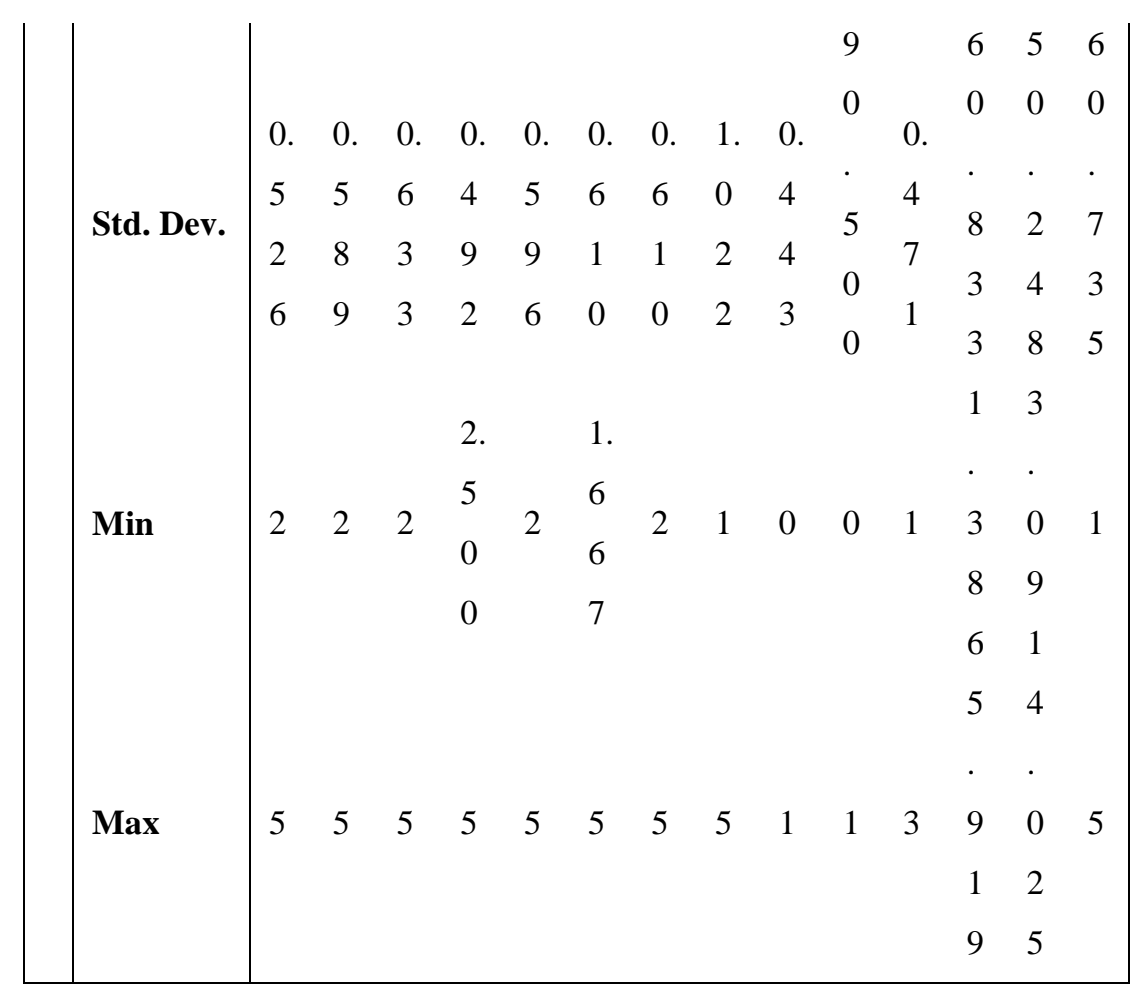


Validating and Expanding The Hawthorne Studies........I Gede Agus Ariutama

RESULTS

The present study is composed of three models with different dependent variables (see table 4.1). Model 1 examined the effects of explanatory variables on self-assessed job performance. The influences of explanatory variables on supervisor-appraised performance as perceived by employees are measured in Model 2. In Model 3, the relationship between independent variables and client-evaluated performance as perceived by employees is investigated. As illustrated in table 4.1, physical work environment and requirement as well as control variables are taken into account in Model As (1A, 2A and 3A), whereas, in Model Bs, (1B, 2B, and 3B) social relations and participation are inserted to the regressions.

In Model 1A, physical conditions variable positively influence self-assessed job performance showing that for a one unit increase in employee's satisfaction on physical conditions, the odds of working well as perceived by the employee increase by the factor of $1.567 \quad(\mathrm{p}<0.10)$. However, in Model 1B, the significance of physical conditions vanishes. For the satisfaction with working hours, none of the models show significant results. In fact, as reported in table 4.1, two variables in the human relations, relations with peers and management, have positive and significant relationship with individual performance as perceived by the employees. A one unit increase in human relation with peers is linked with an increase of 1.958 in the odds that an employee perceives that he performs well $(\mathrm{p}<0.05)$. Likewise, the odds of having better performance compared to worse performance multiply by the factor of 1.716 for a unit increase in the relations with management, given that all other variables are held constant at $95 \%$ significance interval. The second measure of individual performance was supervisor-appraised job performance as perceived by the employees. Satisfaction with physical conditions significantly affects supervisor-appraised job performance. In Model 2A and 2B, a 
one unit increase in the employees' satisfaction on office physical conditions is associated with an increase of 1.741 and 1.624 in the odds that an employee performs well respectively $(\mathrm{p}<0.05)$. By comparing the odds ratios, it can be deduced that the effect of physical conditions reduces as social aspects are included in the model (see table 4.1). Model 2B further illustrates that the more the employees reported being participated in making decision, the more likely they reported as good performers as evaluated by the supervisor. Holding all covariates constant, for a one unit increase in the employees' participation, the odds of performing well as evaluated by supervisor increase by the factor of $1.694(\mathrm{p}<0.05)$.

In Model 3A, satisfaction with physical conditions is the strongest predictors of clientevaluated performance. The odds of having better performance compared to worse performance increase by the factor of 1.905 for a unit increase in the satisfaction with physical conditions, holding all other variables constant at $95 \%$ significance interval. For Model 3B, relations with management and physical conditions variables have positive and significant relationship with job performance as evaluated by clients. For a one unit increase in the employees' perception on relations with management and physical conditions, the odds of working well as assessed by clients increase by the factors of $2.691(\mathrm{p}<0.01)$ and 1.609 $(p<0.10)$ respectively.

Interestingly, job evaluation easiness had a significant influence on all subjective performance measures in the study. As the employees perceive their jobs easier to evaluate, they reported that they work better. The findings also indicate that job difficulty in model $1 \mathrm{~B}$ and $3 \mathrm{~B}$, and respondents' age in model $2(\mathrm{~A}$ and $\mathrm{B})$ and $3(\mathrm{~A}$ and $\mathrm{B})$ are the positive and significant predictors of work performance. Conversely, female employees are less performed than male employees as listed in model 1 (A and B) and 2 (A and B). Work experience also negatively influences the job performance in model 2 (A and B) and 3 ( $\mathrm{A}$ and $\mathrm{B})$. 
Validating and Expanding The Hawthorne Studies........ Gede Agus Ariutama

The relations with emphasize the influences of social management measure have more variables including participation and statistically significant effect on most environment variables on the of the subjective performance performance of employees. Although measures than all explanatory variables. Furthermore, relations with management consistently become a greater variable to predict job performance based on the reported odds ratio, specifically in model $1 \mathrm{~B}$ and $3 \mathrm{~B}$. It is the most important determinant for the job performance as assessed by employees themselves and clients.

\subsection{Discussion}

Hawthorne studies were a significant foundation in the development of human behavior drive in the private setting, which there have been debates on the interpretation of Hawthorne studies, many scholars inferred the more important roles of social relations and participation to the work performance than working environmental variables (Jones, 1990; Jung and Lee, forthcoming). Considering about the existence of the discrepancies between public and private sectors (Golembiewski, 1976; Rainey, 2009) and the absence of empirical study in Asian public organizations, 
Validating and Expanding The Hawthorne Studies........ Gede Agus Ariutama

Table 3. Ordered logit models of individual performance - self-evaluation, supervisor's evaluation and clientele evaluation

\begin{tabular}{|c|c|c|c|c|c|c|c|c|c|c|c|c|}
\hline \multirow{3}{*}{ Ordered Logit } & \multicolumn{4}{|c|}{ Self-Evaluation $(\mathrm{n}=255)$} & \multicolumn{4}{|c|}{ Supervisor Evaluation $(\mathrm{n}=255)$} & \multicolumn{4}{|c|}{ Client's evaluation $(\mathrm{n}=255)$} \\
\hline & \multicolumn{2}{|c|}{ Model 1A } & \multicolumn{2}{|c|}{ Model 1B } & \multicolumn{2}{|l|}{ Model 2A } & \multicolumn{2}{|l|}{ Model 2B } & \multicolumn{2}{|l|}{ Model 3A } & \multicolumn{2}{|l|}{ Model 3B } \\
\hline & $\begin{array}{l}\text { Coef } \\
\text { (SE) }\end{array}$ & OR & $\begin{array}{l}\text { Coef } \\
(\mathrm{SE})\end{array}$ & OR & $\begin{array}{l}\text { Coef } \\
(\mathrm{SE})\end{array}$ & OR & $\begin{array}{l}\text { Coef } \\
\text { (SE) }\end{array}$ & OR & $\begin{array}{l}\text { Coef } \\
(\mathrm{SE})\end{array}$ & OR & $\begin{array}{l}\text { Coef } \\
\text { (SE) }\end{array}$ & OR \\
\hline \multicolumn{13}{|l|}{ 1. Human Relations } \\
\hline Human Relations with Peer & & & $\begin{array}{l}0.672 * * \\
(0.337)\end{array}$ & $\begin{array}{l}1.958^{* *} \\
(0.660)\end{array}$ & & & $\begin{array}{l}0.0111 \\
(0.368)\end{array}$ & $\begin{array}{l}1.011 \\
(0.372)\end{array}$ & & & $\begin{array}{l}0.299 \\
(0.396)\end{array}$ & $\begin{array}{l}1.348 \\
(0.534)\end{array}$ \\
\hline Human Relations with & & & $0.540 * *$ & $1.716^{* *}$ & & & 0.115 & 1.121 & & & $0.990 * * *$ & $2.691 * * *$ \\
\hline Management & & & $(0.262)$ & $(0.449)$ & & & $(0.289)$ & $(0.324)$ & & & $(0.303)$ & $(0.816)$ \\
\hline \multicolumn{13}{|l|}{ 2. Participation } \\
\hline Employees' Participation & & & $\begin{array}{l}0.401 \\
(0.271)\end{array}$ & $\begin{array}{l}1.493 \\
(0.405)\end{array}$ & & & $\begin{array}{l}0.527 * * \\
(0.268)\end{array}$ & $\begin{array}{l}1.694 * * \\
(0.454)\end{array}$ & & & $\begin{array}{l}-0.0235 \\
(0.302)\end{array}$ & $\begin{array}{l}0.977 \\
(0.295)\end{array}$ \\
\hline \multicolumn{13}{|l|}{ 3. Physical Work Environment } \\
\hline Physical Condition & $\begin{array}{l}0.449 * \\
(0.257)\end{array}$ & $\begin{array}{l}1.567 * \\
(0.403)\end{array}$ & $\begin{array}{l}0.272 \\
(0.237)\end{array}$ & $\begin{array}{l}1.312 \\
(0.311)\end{array}$ & $\begin{array}{l}0.554 * * \\
(0.239)\end{array}$ & $\begin{array}{l}1.741 * * \\
(0.416)\end{array}$ & $\begin{array}{l}0.485 * * \\
(0.237)\end{array}$ & $\begin{array}{l}1.624 * * \\
(0.385)\end{array}$ & $\begin{array}{l}0.645^{* * * *} \\
(0.244)\end{array}$ & $\begin{array}{l}1.905^{* * *} \\
(0.465)\end{array}$ & $\begin{array}{l}0.476^{*} \\
(0.252)\end{array}$ & $\begin{array}{l}1.609 * \\
(0.406)\end{array}$ \\
\hline \multicolumn{13}{|l|}{ 4. Physical Work Requirement } \\
\hline Working Hours & $\begin{array}{l}0.184 \\
(0.141)\end{array}$ & $\begin{array}{l}1.202 \\
(0.169)\end{array}$ & $\begin{array}{l}0.166 \\
(0.146)\end{array}$ & $\begin{array}{l}1.180 \\
(0.172)\end{array}$ & $\begin{array}{l}-0.152 \\
(0.140)\end{array}$ & $\begin{array}{l}0.859 \\
(0.120)\end{array}$ & $\begin{array}{l}-0.192 \\
(0.142)\end{array}$ & $\begin{array}{l}0.825 \\
(0.117)\end{array}$ & $\begin{array}{l}0.193 \\
(0.154)\end{array}$ & $\begin{array}{l}1.213 \\
(0.186)\end{array}$ & $\begin{array}{l}0.190 \\
(0.158)\end{array}$ & $\begin{array}{l}1.209 \\
(0.191)\end{array}$ \\
\hline \multicolumn{13}{|l|}{ 5. Control Variables } \\
\hline Female & $\begin{array}{l}-0.618^{*} \\
(0.319)\end{array}$ & $\begin{array}{l}0.539 * \\
(0.172)\end{array}$ & $\begin{array}{l}-0.542 * \\
(0.311)\end{array}$ & $\begin{array}{l}0.582 * \\
(0.181)\end{array}$ & $\begin{array}{l}-0.734 * * \\
(0.328)\end{array}$ & $\begin{array}{l}0.480 * * \\
(0.157)\end{array}$ & $\begin{array}{l}-0.693 * * \\
(0.327)\end{array}$ & $\begin{array}{l}0.500^{* *} \\
(0.163)\end{array}$ & $\begin{array}{l}-0.265 \\
(0.293)\end{array}$ & $\begin{array}{l}0.767 \\
(0.225)\end{array}$ & $\begin{array}{l}-0.176 \\
(0.321)\end{array}$ & $\begin{array}{l}0.839 \\
(0.269)\end{array}$ \\
\hline Bachelor Degree or Above & $\begin{array}{l}0.242 \\
(0.290)\end{array}$ & $\begin{array}{l}1.274 \\
(0.370)\end{array}$ & $\begin{array}{l}0.369 \\
(0.297)\end{array}$ & $\begin{array}{l}1.447 \\
(0.429)\end{array}$ & $\begin{array}{l}-0.556^{*} \\
(0.299)\end{array}$ & $\begin{array}{l}0.573 * \\
(0.171)\end{array}$ & $\begin{array}{l}-0.527^{*} \\
(0.303)\end{array}$ & $\begin{array}{l}0.591 * \\
(0.179)\end{array}$ & $\begin{array}{l}0.243 \\
(0.295)\end{array}$ & $\begin{array}{l}1.275 \\
(0.376)\end{array}$ & $\begin{array}{l}0.338 \\
(0.305)\end{array}$ & $\begin{array}{l}1.402 \\
(0.427)\end{array}$ \\
\hline Job Difficulty & $\begin{array}{l}0.396 \\
(0.290)\end{array}$ & $\begin{array}{l}1.486 \\
(0.431)\end{array}$ & $\begin{array}{l}0.474 * \\
(0.276)\end{array}$ & $\begin{array}{l}1.606^{*} \\
(0.444)\end{array}$ & $\begin{array}{l}0.367 \\
(0.298)\end{array}$ & $\begin{array}{l}1.443 \\
(0.430)\end{array}$ & $\begin{array}{l}0.393 \\
(0.299)\end{array}$ & $\begin{array}{l}1.481 \\
(0.443)\end{array}$ & $\begin{array}{l}0.452 \\
(0.303)\end{array}$ & $\begin{array}{l}1.571 \\
(0.475)\end{array}$ & $\begin{array}{l}0.558^{*} \\
(0.293)\end{array}$ & $\begin{array}{l}1.746^{*} \\
(0.512)\end{array}$ \\
\hline
\end{tabular}


Validating and Expanding The Hawthorne Studies........ Gede Agus Ariutama

\begin{tabular}{|c|c|c|c|c|c|c|c|c|c|c|c|c|}
\hline Tenure (log) & $\begin{array}{l}-0.148 \\
(0.347)\end{array}$ & $\begin{array}{l}0.862 \\
(0.299)\end{array}$ & $\begin{array}{l}-0.0526 \\
(0.356)\end{array}$ & $\begin{array}{l}0.949 \\
(0.338)\end{array}$ & $\begin{array}{l}-0.724 * * \\
(0.340)\end{array}$ & $\begin{array}{l}0.485^{* *} \\
(0.165)\end{array}$ & $\begin{array}{l}-0.716^{* *} \\
(0.347)\end{array}$ & $\begin{array}{l}0.489 * * \\
(0.170)\end{array}$ & $\begin{array}{l}-0.694 * * \\
(0.312)\end{array}$ & $\begin{array}{l}0.499 * * \\
(0.156)\end{array}$ & $\begin{array}{l}-0.649 * * \\
(0.319)\end{array}$ & $\begin{array}{l}0.523 * * \\
(0.167)\end{array}$ \\
\hline Age (log) & $\begin{array}{l}1.315 \\
(1.266)\end{array}$ & $\begin{array}{l}3.725 \\
(4.717)\end{array}$ & $\begin{array}{l}0.639 \\
(1.282)\end{array}$ & $\begin{array}{l}1.894 \\
(2.428)\end{array}$ & $\begin{array}{l}2.823 * * \\
(1.334)\end{array}$ & $\begin{array}{l}16.82 * * \\
(22.45)\end{array}$ & $\begin{array}{l}2.689^{*} \\
(1.401)\end{array}$ & $\begin{array}{l}14.71 * \\
(20.62)\end{array}$ & $\begin{array}{l}2.663 * * \\
(1.218)\end{array}$ & $\begin{array}{l}14.34 * * \\
(17.46)\end{array}$ & $\begin{array}{l}2.142 * \\
(1.208)\end{array}$ & $\begin{array}{l}8.517^{*} \\
(10.29)\end{array}$ \\
\hline Evaluation Easiness & $\begin{array}{l}0.401 * * \\
(0.187)\end{array}$ & $\begin{array}{l}1.494 * * \\
(0.280)\end{array}$ & $\begin{array}{l}0.299 * \\
(0.170)\end{array}$ & $\begin{array}{l}1.348^{*} \\
(0.229)\end{array}$ & $\begin{array}{l}0.597 * * * \\
(0.205)\end{array}$ & $\begin{array}{l}1.816 * * * \\
(0.372)\end{array}$ & $\begin{array}{l}0.498 * * * \\
(0.188)\end{array}$ & $\begin{array}{l}1.646 * * * \\
(0.310)\end{array}$ & $\begin{array}{l}0.521 * * * \\
(0.170)\end{array}$ & $\begin{array}{l}1.684 * * * \\
(0.287)\end{array}$ & $\begin{array}{l}0.468 * * * \\
(0.174)\end{array}$ & $\begin{array}{l}1.597 * * * \\
(0.278)\end{array}$ \\
\hline $\begin{array}{l}* * * \mathrm{p}<0.01, * * \mathrm{p}<0.05, * \mathrm{p}<0.1 \\
\text { Pseudo R2 }\end{array}$ & 0.0423 & & 0.0967 & & 0.0639 & & 0.0782 & & 0.0698 & & 0.1216 & \\
\hline
\end{tabular}


Validating and Expanding The Hawthorne Studies ..I Gede Agus Ariutama

validating and expanding the Hawthorne studies in the public sector will be valuable and critical. Thus, the purpose of this study is to investigate Hawthorne effects from Indonesian public employees.

In general, the major findings in this study support the true effects of Hawthorne studies which emphasize the importance of working relations variables, specifically relations with management over physical work conditions in predicting the performance of employees in public organization. Jung and Lee (forthcoming) revealed that government officials accomplish their duties and responsibilities well as they affirmatively perceived that their working relations with their coworkers and managers are supportive. Furthermore, the result is in line with the argument that workers complete their jobs satisfactorily as they develop good interpersonal confidence, cooperation, and knowledge sharing with coworkers and superiors (Dirks, 1999; Pandey \& Garnett, 2006; Sparrowe, Liden, Wayne \& Kraimer,
2001). As an illustration, Sparrowe et al. (2001) mentioned that team members who share knowledge and cooperate well were appraised more favorably by peers and managers.

Measuring the impact of physical work environment on employees' performance separately from social variables as listed in the results part generates positive and significant outcomes. However, in the full models, which include social and participation factors, the effects of external variables lessen. Still, the influences of physical work conditions factor is significant on the job performance as assessed by supervisor and clients. This finding corresponds to the Jones' investigation (1990) in which the productivity of employees are the results of combined consequence of environmental factors and employees interaction, with the later exerts stronger influence. It can be implied that work environments are nonetheless important factors to predict how well employees work. Carlopio (1996) emphasized the importance of physical conditions as he argued that employees feeling 
satisfied with the physical environmental aspects in their workplace tend to develop a greater association with the organization which is expected to generate more desire to work hard and, thus, increase their performance.

Examining the detailed results in the study, relations with peer and management are the most significant determinants of the selfrating performance significantly. This finding offers confirmation for the aforementioned researches that well-performed employees are influenced directly and indirectly by cooperation and collectivities with coworkers and managers (Astley, 1984; Ring and Van de Ven, 1994) and trust and confidence atmosphere in workplace among employees and between staff and supervisor (Dirks, 1999). Besides, knowledge sharing through familiarities (Goodman and Leyden, 1991), friendship (Jehn and Shah, 1997) and social network (Sparrowe et al., 2001) affects employees and their group performance positively. Another outcome in this study is relations with manager positively affect subjective performance as rated by client. Schmidt (1977) mentioned that effectiveness of public services and their deliveries which emphasize the administrative process could be predicted by how well the coordination between employees and managers. In short, relations with management influence the effectiveness of the service delivery system including the personnel involved as perceived by the users. Thus, it can be observed that public organization should advocate innovative management approach which allows more focus on the importance of social relations factors especially relations with management.

Concerning perceived performance as rated by supervisor, participation of employees is the significant predictor other than physical conditions. When employees are acknowledged for actively engaging in providing suggestions and solutions, they are assessed more positively than passive employees (Sparrowe et al., 2001). It means that supervisors favor employees participating more 
Validating and Expanding The Hawthorne Studies........ Gede Agus Ariutama

in the information exchange and decision-making

process.

Furthermore, Spreitzer, Kizilos, and Nason (1997) support the finding in this study by arguing that individuals' participation will enhance their performance and satisfaction as supervisors and subordinates have balanced and shared participation in knowledge sharing, decision making or problem solving. To sum up, employees perform well as they perceive that their relations with managers and coworkers, participation and physical work environments are favorable with the social relations with management holds to be the strongest explanatory variable.

\section{CONCLUSION}

Mayo (1933) and Morrison (2004) promoted the role of socioemotional topics in the work relationship to determine the behavior of employee, arguing that the degree to which employees perceived and received social satisfaction in the workplace was the most influential factor on employees' productivity directly and indirectly.
This study was carried out to examine this proposition using the Indonesian public setting. The findings in this study reveal that positive perception on social relations and participation does have a significant influence on perceived job performance. The conclusion is in line with the findings in the Hawthorne studies. Additionally, different types of performance measures result in different influential explanatory factors to predict job performance. In the selfassessed job performance, trust, cooperation, and knowledge sharing among coworkers and between staff and superior are more influential than perception on physical conditions of office and working hours. Participation in decision making process and environmental factors best predict job performance appraised by supervisor, whereas, trust and cooperation between subordinates and supervisor explain individual performance as assessed by clients well. Overall, relation with management is the most important predictor of subjective performance. 
Validating and Expanding The Hawthorne Studies........ Gede Agus Ariutama

Considering the importance of social factors to trigger the individual performance in this study, another potential justification, other than Hawthorne theory, to describe the results is collectivism quality of Indonesians. Collectivism refers to a perception of responsibility toward in-group goals, interdependence among group members, emphasis on social harmony, and group norms as determinant of attitudes (Triandis, Chan, Bhawuk, Iwao, \& Sinha, 1995). In this way, social relations with management and peers might generate positive motivation for employees to work better. This study also demonstrates the positive relationship between work environment and individual performance. Furthermore, as the performance of employees is more measurable, the employees accomplish their job better.

Based on the conclusion above, several suggestions can be applied to improve employees' performance. Since Finance Education and Training Agency employed all three self-evaluation, supervisor evaluation, and client evaluation, several strategies to improve relations with coworkers, management and particioation should be utilized. Strategies to be utilized are capacitity building for all employees to improve relations with coworkers and managers, and opportunities and meetings in the office to provide employees to participate in planning and problem solving discussions. Thus, by increasing employees' relations and participation, their performance will improve too.

Several limitations of the present study should also be considered. First, the measures of variables in this study are in the form of self-report with a tendency that people are likely to describe themselves in a more positive manner and do not depict the real condition (Bakker, Hakanen, Demerouti, and Xanthopoupou, 2007). Thus, better measurements involving comprehensive objective data should be utilized. Due to lack of investigation on Hawthorne studies in public setting, further researches on human relations, participation and individual 
Validating and Expanding The Hawthorne Studies........ Gede Agus Ariutama performance with different public of

Educational sectors are expected to confirm the Psychology, 99(2), 274-284 present findings. Moreover, team or section performance should be considered as working relations and participation are important factors to affect performance. Guzzo and Dickson (1996) argued that team effectiveness involved social processes and task processes, meaning intervention on group cohesiveness as part of social processes can promote team performance. Thus, this proposal can generate better understanding on influence of social factors on different measure of performance, specifically team performance.

\section{REFERENCES}

Astley, W. G. (1984). Toward an appreciation of collective strategy. Academy of Management Review, 9(3), 526535.

Bakker, A.B., Hakanen, J.J., Demerouti, E. \& Xanthopoulou, D. (2007). Job resources boost work engagement, particularly when job demands are high. Journal 
Validating and Expanding The Hawthorne Studies........ Gede Agus Ariutama

Caldari, K. (2007). Alfred Marshall's critical analysis of scientific management.The European Journal of the History of Economic Thought, 14(1), 55-78. Carlopio, J. R. (1996). Construct validity of a physical work environment satisfaction questionnaire. Journal of Occupational Health Psychology, 1(3), 330.

DeMaris, A. (1993a). Odds versus probabilities in logit equations: A reply to Roncek. Social Forces, 71, 1057-1065.

Dirks, K. T. (1999). The effects of interpersonal trust on work group performance. Journal of Applied Psychology, 84(3), 445.

Franke, R. H., \& Kaul, J. D. (1978). The hawthorne experiments: First statistical interpretation. American Sociological Review, , 623-643.

Golembiewski, R. T. (1976). Perspectives on public management: Cases and learning designs (2nd ed.). Itasca, IL: F.E. Peacock Publishers.
Goodman, P. S., \& Leyden, D. P. (1991). Familiarity and group productivity. Journal of Applied Psychology, 76, 578-586.

Government Regulation of structural promotion for public officials number 13, 2002. (2002). Retrieved from http://www.bkn.go.id/in/profil/u nit-kerja/organisasi-deputikinerja-danperundangan/direktoratperaturan-perundangundangan/kumpulanperaturan/finish/54/540.html Guzzo, R. A., \& Dickson, M. W. (1996). Teams in organizations: Recent research on performance and effectiveness. Annual review of psychology,47(1), 307-338.

Hart, C. (1943). The hawthorne experiments. Canadian Journal of Economics and Political Science, , 150-163.

Homans, G. C. (1992). The human group. Transaction Publishers.

Izawa, M. R., French, M. D., \& Hedge, A. (2011). Shining new light on the Hawthorne Illumination 
Validating and Expanding The Hawthorne Studies........ Gede Agus Ariutama

Experiments. Human Factors:

The Journal of the Human

Factors and Ergonomics

Society, 53(5), 528-547.

Jehn, K. A., \& Shah, P. P. (1997). Interpersonal relationships and task performance: An examination of mediation processes in friendship and acquaintance groups. Journal of Personality and Social Psychology, 72(4), 775.

Jones, S. R. (1990). Worker interdependence and output: The Hawthorne studies reevaluated. American Sociological Review, 55, 176-190.

Jones, S. R. (1992). Was there a Hawthorne effect?. American Journal of Sociology. 98 (3), 451-468.

Jung, C. S., \& Lee, S. (forthcoming). The hawthorne studies revisited: Evidence from the US federal workforce. Administration \& Society, , 0095399712459731.

Kim, S. (2002). Participative management and job satisfaction: Lessons for management leadership. Public
Administration Review, 62(2), 231-241.

Landsberger, H. A. (1958).

Hawthorne revisited:

Management and the worker, its critics, and developments in human relations in industry Cornell University Ithaca, NY.

Liang L, Chaloupka FJ (2002). Diffe rential effects of price on youth smoking intensity. Nicotine \& Tobacco $R$ esearch, 4, 109-114.

Likert, R. (1967). The human organization: Its management and values.

Locke, E. A. (1982). The ideas of Frederick W. Taylor: an evaluation. Academy of Management Review, 7(1), 1424.

Marquardt, C. J., Veitch, J. A., \& Charles, K. E. (2002). Environmental satisfaction with open-plan office furniture design and layout. Institute for Research in Construction.

Marshall, A. (2006). Industry and trade (Vol. 2). Cosimo, Inc..

Mayo, E. (1933). Human problems of an industrial civilization. 
Validating and Expanding The Hawthorne Studies ..I Gede Agus Ariutama

McGregor, D. (2000). The Human Side of Enterprise. Reflections (Cambridge, Mass.), 2(1), 6-6.

Meier, K. J., \& O'Toole Jr, L. J. (2013). I think (I am doing well), therefore I am: Assessing the validity of administrators' selfassessments of performance. International Public Management Journal, 16(1), 127.

Morrison, R. (2004). Informal relationships in the workplace: Associations with job satisfaction, organisational commitment and turnover intentions. New Zealand Journal of Psychology, 33(3).

Mortagy, A., \& Ramsey, J. (1973). Monitoring performance as a function of work/rest schedule and thermal stress. The American Industrial Hygiene Association Journal, 34(11), 474-480.

Newsham, G., Brand, J., Donnelly, C., Veitch, J., Aries, M., \& Charles, K. (2009). Linking indoor environment conditions to job satisfaction: A field study.
Building Research \& Information, 37(2), 129-147.

Olson, R., Verley, J., Santos, L., \& Salas, C. (2004). What we teach students about the hawthorne studies: A review of content within a sample of introductory IO and $\mathrm{OB}$ textbooks. The Industrial-Organizational Psychologist, 41(3), 23-39.

Ouchi, W. G. (1980). Markets, bureaucracies, and clans. Administrative science quarterly, 25(1).

Pandey, S. K., \& Garnett, J. L. (2006). Exploring public sector communication performance: Testing a model and drawing implications. Public Administration Review, 66(1), $37-51$.

Parsons, H. M. (1978). What caused the Hawthorne effect? A scientific detective story. Administration and Society, 10, 259-283.

Perrow, C. (1986). Complex organizations: A critical essay. New York, NY: McGraw-Hill. Rainey, H. G. (2003). Understanding and managing public 
Validating and Expanding The Hawthorne Studies .I Gede Agus Ariutama organization (3rd ed.). San Francisco, CA: Jossey-Bass.

Ring, P. S., \& Van de Ven, Andrew H. (1994). Developmental processes of cooperative interorganizational relationships. Academy of Management Review, 19(1), 90-118.

Roethlisberger, F. J. (1941). The hawthorne experiments. Classics of Organization Theory, 6, 158-166.

Roethlisberger, F. J., \& Dickson, W. J. (1967). Management and the worker. Cambridge, MA: Harvard University Press.

Schmidt, S. M. (1977). Clientoriented evaluation of public agencies effectiveness. Administration \& Society, 8(4), 403-422.

Scott, W. R. (2003). Organizations: Rational, natural, and open systems (5th ed.). Upper Saddle River, NJ: Prentice Hall.

Sparrowe, R. T., Liden, R. C., Wayne, S. J., \& Kraimer, M. L. (2001). Social networks and the performance of individuals and groups. Academy of
Management Journal, 44(2), 316-325.

Spreitzer, G. M., Kizilos, M. A., \& Nason, S. W. (1997). A dimensional analysis of the relationship between psychological empowerment and effectiveness satisfaction, and strain. Journal of Management, 23(5), 679-704.

Taylor, F. W. (1911). The principles of scientific management. New York, 202.

Triandis, H. C., Chan, D. K., Bhawuk, D. P., Iwao, S., \& Sinha, J. B. (1995). Multimethod probes of allocentrism and idiocentrism. International Journal of Psychology, 30(4), 461-480.

Wagner, J. A. (1994). Participation's effects on performance and satisfaction: A reconsideration of research evidence. Academy of Management Review, 19(2), 312-330.

Wan, A. T., Zhang, X., \& Wang, S. (2014). Frequentist model averaging for multinomial and ordered logit models. 
Validating and Expanding The Hawthorne Studies........ Gede Agus Ariutama International Journal of White, M., Hill, S., McGovern, P., Forecasting, 30(1), 118-128. Mills, C., \& Smeaton, D. (2003).

Wang, L. M., \& Novak, C. C. (2010). 'High-performance'

AB-10-019: Human performance and perceptionbased evaluations of indoor noise criteria for rating mechanical system noise with time-varying fluctuations (1322RP). Architectural EngineeringFaculty Publications. Paper 41. Whitehead, J. (1993). Sample size calculations for ordered categorical data. Statistics in Medicine, 12(24), 2257-2271. Management Practices, Working Hours and Work-Life Balance.British Journal of Industrial Relations, 41(2), 175195.

Witterseh, T., Wyon, D. P., \& Clausen, G. (2004). The effects of moderate heat stress and open-plan office noise distraction on SBS symptoms and on the performance of office work. Indoor Air, 14(s8), 30-40. 